\title{
付着生物対策と電気事業 一対策を実施する立場からみた課題一
}

清野通康

\section{財団法人海洋生物環境研究所 中央研究所 $\bar{T}$ 299-5105 千葉県夷隅郡御宿町岩和田 300}

\section{Control of biofouling in power plant cooling water systems \\ - Discussion of practical research targets from a user's view -}

\section{Michiyasu Kiyono}

Central Laboratory, Marine Ecology Research Institute, 300 Iwawada, Onjuku-machi, Chiba 299-5105, APAN

Email: kiyono@kaiseiken.or.jp

\begin{abstract}
Biofouling control of cooling water systems has been one of the severe problems for power plant operation. A lot of works have been carried out and many physical/chemical control methods are available. However, practical measures satisfied following criteria have not been developed : (1)reliable control for a long enough term, (2)broad availability, (3)low environment impacts, (4)simply operating, and (5)reasonable cost. Power plants have been coping with biofouling, using a combination of some measures applicable. Possible research targets of practical anti-biofouling are discussed from a user's view.
\end{abstract}

Key words: biofouling, power plant, cooling water system, measures

わが国の火力・原子力発電所は殆どの地点で冷却用水 として海水を使用する。そのため海水とともに泠却水路 に流入・付着する海生生物への対策は、発電所の円滑な 運用を図るための歴史的課題のひとつとなっている。

付着生物の生理・生態や防除対策については、多くの 先賢の研究実績があり着々と知見が蓄積されている。し かしながら、将来の幅広い適用を期待させるシーズが生 まれてきてはいるものの、現状では、まだ、充分な効果 があり、環境保全性に優れ、コストも適切である対策技 術は実用化されていない。発電所においては防除対象と する設備構造とその運用状況を考慮して、開発されてい る多数の技術の中から適切な技術を選択・利用すること による対応がなされている。

筆者は発電所における付着生物対策にこれまで何度か 係わったことはあるものの、その専門家ではなく、表記
のような課題について述べることはおこがましいが、防 除対策を実施する立場から見て必要と考えられる情報な どについて私見を紹介する。なお、以下は平成 13 年度日 本付着生物学会シンポジウム「付着生物研究と電気事業」 において述べたものの概要である。

\section{発電所における付着生物対策の現状}

社団法人火力原子力発電技術協会の環境対策技術調査 委員会では、平成 4 年にわが国の全火力発電所（100 地 点、計 296 ユニット）を対象にアンケート調査を実施し た。やや古いデータではあるが、この調査データに若干 補足しながら、確認の意味を含めて発電所における付着 生物対策の概要について簡単に触れる。

同アンケート調査によると、発電所当たりの付着生物 回収量は年間数トン〜数 100 トンとなる地点が多く 1,000 
トンを超す地点もある。ほぼ半数の地点で過去に付着生 物による何らかのトラブルを経験しており、年間の付着 生物回収量が 100 トンを超えるとトラブルが増加する傾 向がある。また、回収量の多い地点では、いずれの地点 も回収した付着生物の処理・処分に苦慮している。

防除対策の主体は塩素処理と防污塗装にある。塩素供 給は殆どが海水電解で低濃度注入を行っている。上記ア ンケート調查時には、296 火力ユニット中、半数強のユ ニットで何らかの塩素処理が行われていた（補機系のみ に利用しているユニットを含む）。一方、同アンケート調 查終了後に運開や増設を行った火力発電所で塩素処理 （海水電解）を導入したユニット数は $1 / 3$ 強であり、海 域によって状沉は異なるものの塩素利用は控えられる傾 向にある。シリコン系塗装など防污塗料を使う発電所は 増加傾向にある。塗装による防污は充分期待できるが、 耐久性や施工性、海域による効果差、曲管部対策などが 課題として残されている。

付着生物対策を困難にしている要因のひとつに、多様 な自然とともに立地条件を反映した多様な発電所構造と、 社会状況の変化を反映した運用の多様さがある。

例えば、取水路の長さひとつを取ってみても、10 $\mathrm{m}$ 程度 の地点から $1,000 \mathrm{~m}$ を超える地点まである。新しい課題 としては、複数ユニットで共通利用する取水路など構造 や発電所運用上、干出できない水路への対策や、需要に 応じた頻繁な稼働・減負荷・停止を繰り返し行っている 発電所への対策などがあげられる。

\section{付着生物対策選定の要件}

発電所サイドから見た付着生物対策選定の要件を示す と以下のようになろう。

1。確実な効果が長期間持続する。

2. 適用範囲が広く、立地点・構造・生物種によらず 適用できる。

3。環境影響が小さい。

4. 施工・保守管理が容易で施設運転中に防污ができ る。

5。コストが適切。

常識的なことばかりであるが、現状では、これらの要 件を充分に満足寸る技術はまだ実用化されていない。な お、対策に伴う新たなエネルギ一負荷が少ないというこ とも重要と考える。この意味では、わが国でも一部で検 討が進められ、米国などでは既に実用化されている排熱 利用による付着生物防除は、防除に利用した後の熱排出 に工夫が必要であるが考慮に值する対策のひとつである う。また、海に付着生物が棲むのは自然であり、発電所 と周辺海域の付着生物群集の共存を図り得ることが対策 実施の基本となると考える。

\section{対策を実施する立場からみた課題}

先に述べたように、発電所では現状様々な防污対策を 組合せながら対応している。この努力の結果、問題が目 立たなくなった地点もある。しかしながら、将来を考え ると、付着生物対策が定検間隔の延長・定検期間の短縮 など発電所利用効率向上のネックとなる可能性がある。 また、生物毒となり得る防污材利用は一層制限される、 さらに、回収した付着生物の処理・処分は益々困難とな るなどの懸念があるので、より適切な対策技術が必要と いうのが、実際付着生物対策に携わっている方々の実感 であろうと考える。

以下、「より適切な対策技術が必要」ということを説得力 を持って説明するにはどうしたら良いか、対策を実施す る立場からどのような知見や技術が望まれるかなどにつ いて、やや総論的となるが私見を述べさせていただく。 実際に対策技術開発や対策実施を担当する立場になっ た時に感じる質問は次のようなものとなろう。

Q何が何時付着する?

$\mathrm{Q}$ どんな対策があり、どれが適切か?

$\mathrm{Q}$ コストは適切か?

Q環境影響の懸念は?

$\mathrm{Q}$ 生物付着の問題は何処に?（新たな）対策が必要 加?

何れも基本的な質問であるが、現状これらに答えられ る形で、知見の集積・整理が行われているであろうか。筆 者も生物を専攻してきたので割り切って回答できる程生 物現象は簡単でないことは判るが、これらの質問に対し て関連学協会や業界が、どう対応しようとしているのか、 単に筆者の勉強不足だけかもしれないが、見えにくいと 感じてきた。これらに直ぐ適切に答えることはもちろん 難しいであろうが、将来的には、これらの質問に回答で きる知見をそろえる必要があると考える。

ここでは、上記の質問に関連し、筆者が付着生物対策 を開発または実施する立場に立ったら、先ず、欲しい知 見を紹介寸る。知見の蓄積がまだ充分でないなら、それ らは今後の課題となろう。一方、専門の方々にとって既 に充分な情報があるものであるなら、それらの知見を体 系的にまとめていただきたいと考える。

\section{Q何が何時付着する？}

管路に出現する生物について、陸上植物で作成されて いる潜在植生図のような「付着生物 (潜在的) 出現相マッ プ」があるとより具体的な対策が考えやすい。開放され た場と管路内の生物相の違いについては数多くの事例報 告があるが、海域毎に管路内の生物相の特徴についてま とめたものはないように思う。出現する生物種はもちろ ん複雑であろうし、また、新たに侵入する生物も次々に 
出現するとは思われるが、光がなく、定常的に海水が一 方向に流れ、また、定住するプランクトンや遊泳動物が いない管路の環境に出現する生物相は、外界に比べると より整理しやすいのではないか。

\section{Qどんな対策があり、どれが適切か?}

既存技術については、既に、日本付着生物学会や電気 化学協会の海生生物污損対策懇談会などでまとめられた ものがあり、また、技術の評価実験情報の共有化は事業 者大で進められつつある。ただ、多くの場合、既存資料 は対策技術そのものに関する記載が中心であり、また、 殆ど全ての付着生物種を除去することを考えた対策評価 となっているように見える。海の付着生物は様々なもの が出現し総合的な対策が望ましいとは思うが、もし、海 域や施設によって特定種が問題になるならば、復水器細 管でのスライム対策のように特定な生物を狙った対策が あっても良いと考える。ひとつの種を除いても次々に新 しい種が付着しようが、大きな障害を引き起こす問題生 物群に対してのみ効果がある方策で対応できるなら、そ れは環境保全上も優れた方法となろう。

\section{Q環境影響の懸念は?}

環境影響がゼロという対策はなく、利用可能なべター な方法を選択し利用することとなろう。環境影響に関し ては、現在利用している技術、例えば、低濃度塩素、防 污塗装などのリスクの大きさが新しい技術を評価・選定 する際の基準となるので、製造・施工課程なども含めた 既存技術のリスク評価を行っておくことが望ましい。現 行対策技術の環境リスクは、大きいかもしれないし、小
さいかもしれない。

\section{Qコストは適切か?}

\section{Q生物付着の問題は何処に？（新たな)対策が必要か?}

他の条件を満たすならコストは低い方が良いことはい うまでもない。ただ、コストの適否の判断を行うには、生 物付着による発電ロス（熱伝導率の低下によるロス、定 検や管路清掃の長期化によるロス、付着生物対策のため の施設費など）を把握しておく必要があろう。明確に分 けがたい部分もあろうが、これらの数值は対策の意味や 対策のための適正なコスト、対策技術開発研究の必要性 を考える際の重要な情報となる。なお、Electric Power Research Institute （カリフォルニア州、米国）は、生物 付着による全米での発電ロスを伝熱ロスも含めて年間10 億ドルと推定している。米国の発電施設容量は日本の 3 倍程度あるが、発電用取水源は主に河川・湖沼である。米 国淡水域での大型付着生物種はゼブラガイなどに限られ るため、わが国の付着生物問題はより切実と考える。

以上、生物付着対策を実施する立場からみた今後の課 題について述べた。現状、発電所の現場では、色々な課 題を抱えながら担当者の方々の工夫と努力で何とか対応 してきている。今後、もう少し既存技術を改良すれば現 場の苦労が減るのか、それとも、何らかの新たな技術開 発が必要なのか。また、今ここで技術開発の手を抜くと 将来どうなるのか。これらに答えるか、少なくとも検討 の方向性を示すことができれば、発電所の付着生物対策 は大きく前進するものと考える。今後の付着生物研究の 進展を期待する。 